\title{
Psychological Implications of Customer Participation in Co-Production
}

Customer participation in the production of goods and services appears to be growing. The marketing literature has largely focused on the economic implications of this trend and has not addressed customers' potential psychological responses to participation. The authors draw on the social psychological literature on the self-serving bias and conduct two studies to examine the effects of participation on customer satisfaction. Study 1 shows that consistent with the self-serving bias, given an identical outcome, customer satisfaction with a firm differs depending on whether a customer participates in production. Study 2 shows that providing customers a choice in whether to participate mitigates the self-serving bias when the outcome is worse than expected. The authors present theoretical and practical implications and provide directions for further research.

C ustomers increasingly are being encouraged to take on more active roles in producing goods and services. They go into photography stores and use machines to crop, enlarge, correct, or enhance their photographs; check themselves in and out of hotels; and even routinely scan and bag their own groceries at supermarkets. Customer participation per se is not new. Supermarkets, which are models of customer co-production with customers selecting, carting, and transporting groceries, date to the 1930 s. What is new is the recognition that encouraging customers to be "co-producers" in this sense is the next frontier in competitive effectiveness. We are seeing the emergence of the "customizing consumer" (Moyers 1989)-consumers who examine market offerings and create a customized consumption experience for themselves (Firat, Dholakia, and Venkatesh 1995). On the basis of this trend, Lovelock and Young (1979) urge firms to use customers to increase productivity. Schneider and Bowen (1995) suggest that firms should use customer talents to deliver superior service. Lengnick-Hall (1996) urges firms to examine the roles that customers can and do play in the service production process. Recently, Prahalad and Ramaswamy (2000) have advocated co-opting customer competence as a competitive strategy. This shift in the perspective of companies to viewing customers as active co-producers rather than as a passive audience is captured in the move from "What can we do for you?" to "What can you do with us?" (Wind and Rangaswamy 2000).

Until recently, the logic of these exhortations has relied almost exclusively on an economic rationale. Simply stated, when customers participate in production, it frees up labor costs and enables a firm to market the offering at a lower monetary price, resulting in a win-win situation in the

Neeli Bendapudi is Associate Professor of Marketing, and Robert P. Leone is Professor and Berry Chair in Marketing, Fisher College of Business, Ohio State University. buyer-seller relationship (Fitzsimmons 1985). Note that it is the monetary price that is generally lower through customer participation in production. The total cost, comprising monetary price and nonmonetary aspects such as time, effort, and other psychic access costs (Heskett, Sasser, and Schlesinger 1997), may be higher in customer participation for both firms and customers. Although the monetary dimension of participation has received attention, little is known about the effect participation may have on a customer's psychological processes and evaluations. No prior studies have considered explicitly the impact on a customer's psychological response, such as satisfaction, despite calls for such a broader framework (e.g., Czepiel 1990; Dabholkar 1990; Lusch, Brown, and Brunswick 1992; Prahalad and Ramaswamy 2000).

We offer the first empirical investigation of a customer's psychological response to participation in production. Research in social psychology on the self-serving bias forms the theoretical basis for our examination. Literature on the self-serving bias examines how a person assigns responsibility for jointly produced outcomes (Miller and Ross 1975; Sedikides et al. 1998; Zuckerman 1979). In two studies, we examine (1) how the self-serving bias affects a customer when he or she participates in production and (2) how providing a customer the choice of whether to participate affects this relationship. We conclude with a discussion of the practical and theoretical implications of the studies.

\section{Literature Review}

\section{Customer Participation in the Production of Goods and Services}

Customer participation has been defined as "the degree to which the customer is involved in producing and delivering the service" (Dabholkar 1990, p. 484). Extending this construct, Meuter and Bitner (1998) distinguish among three types of service production based on customer participation: 
firm production, joint production, and customer production. Firm production is a situation in which the product is produced entirely by the firm and its employees, with no participation by the customer. Joint production is a situation in which both the customer and the firm's contact employees interact and participate in the production. Customer production is a situation in which the product is produced entirely by the customer, with no participation by the firm or its employees. The purpose of this article is to understand how customers' psychological responses may vary when they have no participation (firm production) versus some production participation (joint production). Therefore, we do not consider the situation of customer production and selfservice technologies (Meuter et al. 2000), and when we refer to participation, we mean the joint production of outcomes.

The relevant literature on customer participation in the production of goods and services is summarized in Table 1. An examination of Table 1 reveals two important themes. First, the early work in the area focused largely on the firm, making a business case for why customers should engage in the production process. The benefits to the firm of such customer participation were defined in terms of productivity gains, with customer labor substituting for employee labor (e.g., Fitzsimmons 1985; Lovelock and Young 1979; Mills, Chase, and Margulies 1983; Mills and Morris 1986).

The second theme that emerges is the focus on managing customers as partial employees and the applications and limits of traditional employee management models (e.g., Kelley, Donnelly, and Skinner 1990; Lengnick-Hall 1996; Mills and Moberg 1982). Research in this theme has focused on identifying when customers may be motivated to participate in production as partial employees, such as the effect of propensity for do-it-yourself projects (Bateson 1985), technology readiness (Dabholkar 1996), provision of adequate training (Goodwin 1988), and the resources and constraints in the trade-offs between different levels of customer participation (Lusch, Brown, and Brunswick 1992). Fodness, Pitegoff, and Sautter (1993) examine the potential negative effects of training customers as employees. However, they focus only on the economic effects of creating potential competitors, not the psychological responses.

A broader perspective of co-production is found in the interpretive marketing literature (Firat, Dholakia, and Venkatesh 1995; Firat and Venkatesh 1993). These researchers suggest that a fundamental characteristic of the postmodern era is the reversal of production and consumption: The consumer is usurping the privileged status previously accorded to the producer. Concurrently, Firat, Dholakia, and Venkatesh (1995, p. 50) argue that "the consumer may be finding the potential (sic) to become a participant in the customization of his/her world." Firat and Venkatesh (1995) suggest that customers are demanding a role in production and that to satisfy them, marketers must open up more and more of their processes and systems to consumers' active participation.

Although these studies shed some light on customer participation, the psychological consequences of this phenomenon have been studied only in a limited fashion (Song and Adams 1993). Some authors have suggested that participation may have other important effects on customer satisfac- tion (Czepiel 1990; Van Raaij and Pruyn 1998; Wind and Rangaswamy 2000), but the paths of this influence have not been specified clearly, and no tests of this effect have been reported. This lack makes it impossible to draw strong conclusions about the effects of participation on customer satisfaction. The previous literature also has focused primarily on the service arena. Although in the past customer participation was much more likely with services than with goods, recent technological advances and competitive realities are creating opportunities for customers to participate in the production of goods (Peppers and Rogers 1997). Thus, we believe it is critical to examine the effects of customer participation in the production of goods as well as services.

\section{Potential Psychological Responses to Customer Participation in Production: The Role of the Self- Serving Bias}

Literature on the self-serving bias, a specific area of attribution research that has received limited attention in the marketing literature (Curren, Folkes, and Steckel 1992; Folkes 1988), appears to be especially appropriate in studying psychological responses to customer participation in production. The self-serving bias refers to a person's tendency to claim more responsibility than a partner for success and less responsibility for failure in a situation in which an outcome is produced jointly (Wolosin, Sherman, and Till 1973).

Researchers in the social psychological arena investigating the self-serving bias in jointly produced outcomes have focused on dyadic relationships. Under this paradigm, dyads, strangers to each other, are asked to work together on a specific task. Following the task, the subjects are given bogus success or failure feedback on the task. Subsequently, subjects are asked to provide confidential assessments of their own and their partner's contribution to the task outcome. Campbell and colleagues (2000) identify five lab-based studies that examine the self-serving bias in interdependent outcome contexts (Johnston 1967; Sedikides et al. 1998; Wolosin, Sherman, and Till 1973). Johnston (1967) had subjects believe they were working with a partner, situated in another room, to manipulate a control knob to hold a moving cursor steady at zero. This was a novel task to subjects. After three sessions of 20 trials each, subjects were given bogus success or failure feedback about the dyad's performance. The self-serving bias was not observed in this study.

Arguing that the novelty of the task mitigated the selfserving bias, Wolosin, Sherman, and Till (1973) demonstrate the self-serving bias in two studies. They had pairs of subjects work on decision-making tasks under cooperative or competitive situations; also subjects were asked to assign responsibility to themselves, their partners, or to the situation following bogus success or failure feedback to the dyad. In cooperative situations (subjects and partners working together), subjects tended to take more responsibility for themselves under success feedback, whereas they attributed more responsibility to the partner in the failure feedback condition. In competitive situations (subjects competing with partners), subjects who received success feedback claimed more responsibility than those who received failure feedback; the latter subjects attributed more responsibility to the situation than to 
TABLE 1

A Chronological Review of the Literature on Customer Participation in Production

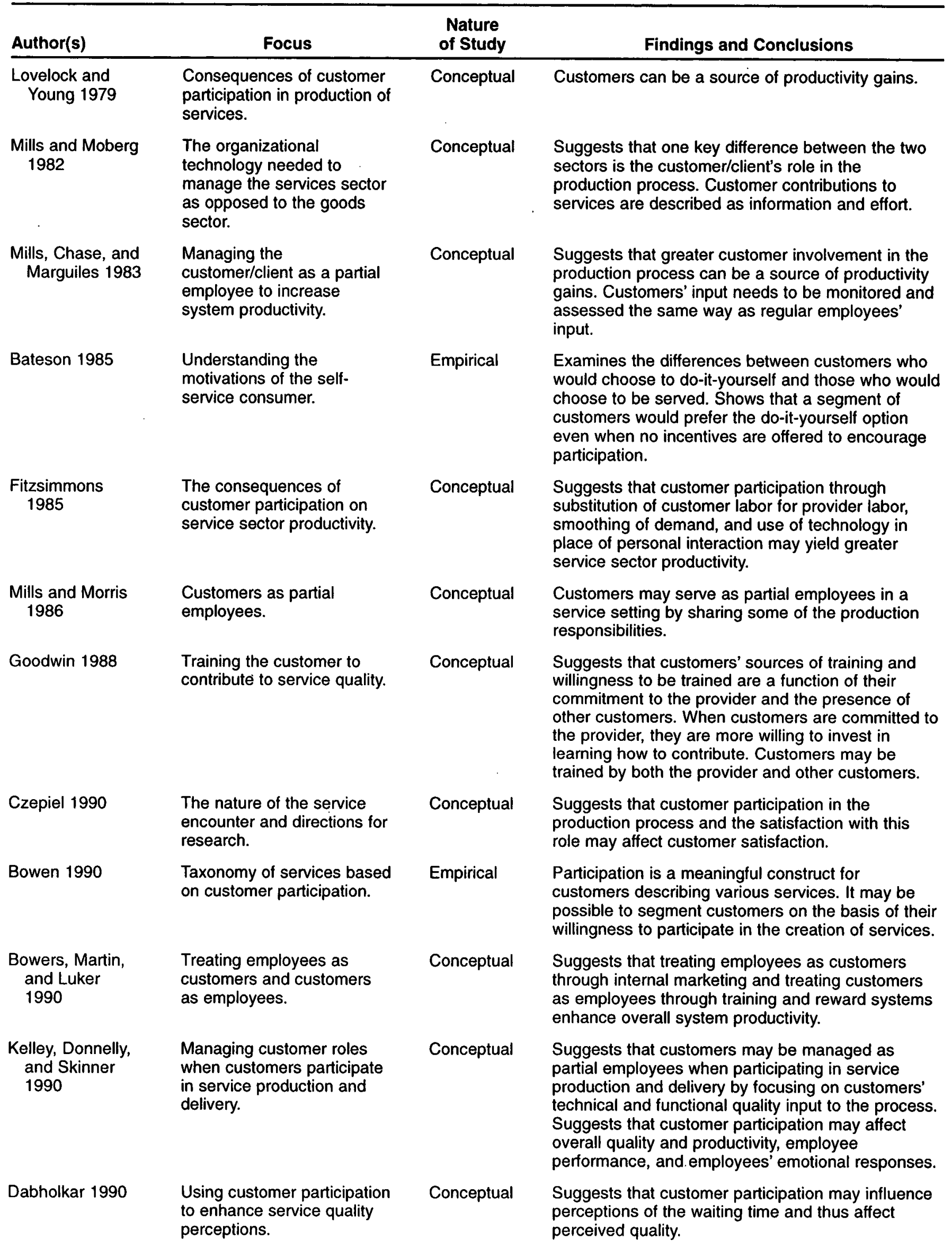


TABLE 1

(Continued)

\begin{tabular}{|c|c|c|c|}
\hline Author(s) & Focus & $\begin{array}{l}\text { Nature } \\
\text { of Study }\end{array}$ & Findings and Conclusions \\
\hline $\begin{array}{l}\text { Fodness, } \\
\text { Pitegoff, and } \\
\text { Sautter } 1993\end{array}$ & $\begin{array}{l}\text { The downside of customer } \\
\text { participation. }\end{array}$ & Conceptual & $\begin{array}{l}\text { Suggests that customers who are trained to do } \\
\text { more of the service for themselves may develop } \\
\text { into a potential competitor by performing for } \\
\text { themselves services that were previously } \\
\text { purchased. }\end{array}$ \\
\hline $\begin{array}{l}\text { Firat and } \\
\text { Venkatesh } \\
1993\end{array}$ & $\begin{array}{l}\text { Argues for the reversal of } \\
\text { roles of consumption and } \\
\text { production. }\end{array}$ & Conceptual & $\begin{array}{l}\text { Among the postmodern conditions discussed is the } \\
\text { reversal of consumption and production as } \\
\text { customers take on more active roles in production. }\end{array}$ \\
\hline $\begin{array}{l}\text { Song and Adams } \\
1993\end{array}$ & $\begin{array}{l}\text { Using customer participation } \\
\text { in production and delivery } \\
\text { as opportunities for } \\
\text { differentiation. }\end{array}$ & Conceptual & $\begin{array}{l}\text { Customer participation should not always be } \\
\text { examined merely as a cost-minimization problem. } \\
\text { Instead, firms can examine opportunities for } \\
\text { differentiating their market offering by heightening o } \\
\text { lessening customers' participation in the production } \\
\text { and delivery of products. }\end{array}$ \\
\hline $\begin{array}{l}\text { Cermak, File, and } \\
\text { Prince } 1994\end{array}$ & $\begin{array}{l}\text { Distinguishing participation } \\
\text { versus involvement effects. }\end{array}$ & Empirical & $\begin{array}{l}\text { Attempt to distinguish involvement from } \\
\text { participation, but authors conclude that participation } \\
\text { construct was confounded by operationalization as } \\
\text { level of involvement. }\end{array}$ \\
\hline $\begin{array}{l}\text { Firat and } \\
\text { Venkatesh } \\
1995\end{array}$ & $\begin{array}{l}\text { Distinguishes between the } \\
\text { consumer perspectives of } \\
\text { modernism and } \\
\text { postmodernism. }\end{array}$ & Conceptual & $\begin{array}{l}\text { Argues that the modernist perspective confines the } \\
\text { consumer by arguing for the "privileging" of } \\
\text { production over consumption. Postmodernism } \\
\text { provides a basis for understanding a greater } \\
\text { consumer role in production as well as } \\
\text { consumption. }\end{array}$ \\
\hline
\end{tabular}

Firat, Dholakia, and Venkatesh, 1995

Hult and Lukas 1995

Lengnick-Hall 1996

Van Raaij and Pruyn 1998

Prahalad and Ramaswamy 2000

Wind and Rangaswamy 2000
Presents a postmodern perspective of consumer as customizer and producer.

Customer participation in health care.

Conceptual

Conceptual quality.

Customer control and its impact on judgments of service validity and reliability.

Coopting customer competence.

Conceptual

Customerization: The next revolution in mass customization.

Conceptual

Conceptual
As consumers have become customizers, marketing organizations' offerings will increasingly become processes rather than finished products. Consumers who are integrated into the production systems will need to be conceptualized as producers.

Suggests that classifying health care tasks in terms of customer participation and complexity of the task has important implications for marketing the services.

Customers influence quality by their roles: as resources, as co-producers, as buyers, as users, and as product. Garnering customer talents in these roles can yield competitive advantages.

Suggests that customers may perceive more or less sense of control in three stages in the service relationship: input, throughput, and output. The greater the sense of control, the more customers will feel responsibility for and satisfaction with the service.

The changing roles of customer from passive audience to active cocreators of experience. Companies can achieve a competitive advantage by leveraging customer competence.

Conceptual In the digital marketplace, customers are becoming active participants in product development, purchase, and consumption. Firms must become customercentric and adopt "customerization" to add value. 
themselves. Curren, Folkes, and Steckel (1992) find a similar pattern of results in marketing decision making: In a marketing decision-making simulation task, people claim that their success is due to factors internal to themselves whereas their failure is attributed to external factors.

Sedikides and colleagues (1998) induced closeness in strangers and then asked the dyads to work together to come up with as many uses for an object, a brick, and a candle as they could in five minutes and were given bogus success or failure feedback. The induced closeness reduced the selfserving bias so that subjects accepted responsibility both for success and for failure. Campbell and colleagues (2000) replicated this study by recruiting subjects to work in dyads with their friends or with strangers. Strangers were more likely to take credit for success and blame the partner for failure, whereas friends took responsibility for both success and failure outcomes when assessing the output of their dyad.

These studies of individuals engaging in jointly producing outcomes are similar to situations in which customers work with firms and participate in the production of a deliverable. The customer and the firm jointly produce an outcome, and the customer assigns responsibility to the firm and to him- or herself. Our first study explores the self-serving bias when customers participate in production and investigates its impact on customer satisfaction judgments.

\section{Study 1: The Self-Serving Bias in Participation and the Impact on Satisfaction}

The objective of this study is to examine whether the selfserving bias can be extended to relationships between a customer and a firm. Investigating this extension is interesting for several reasons. First, it is not obvious whether the bias would hold in the commercial arena. For example, in customer-firm relationships, because customers are paying for the good or service, they always might hold the seller more responsible for the outcome, whether they participate or not. Alternatively, customers in relationships with firms may be hypervigilant to what each party gives and gets, and thus they may be less likely to be subject to this bias. Second, previous studies have focused only on bogus feedback regarding success and failure in the task provided by a third party. In a typical consumption situation, the customer actually makes this judgment and then must assign credit or blame.

Traditional explanations have assumed that customer participation may affect customer satisfaction by lowering the price. However, the self-serving bias literature suggests an additional mechanism that may affect customer satisfaction. Relative to the traditional situation in which the customer does not participate in the production of goods and services, in the joint production condition, the customer participates in some part of the production process. Thus, the customer must allocate the credit for a positive outcome or the blame for a negative outcome to him- or herself and to the firm, which in turn may affect a customer's satisfaction.

\section{The Self-Serving Bias and Outcome Quality}

Outcomes frequently are characterized in the marketing literature as better than expected, as expected, or as worse than expected (Zeithaml, Berry, and Parasuraman 1993). When the outcome is better than expected, the self-serving bias theory suggests that a person assumes greater responsibility for the outcome (Campbell and Sedikides 1999). Thus, a customer should give him- or herself greater credit for the outcome than he or she gives to the production partner, the firm. In contrast, when a customer does not participate in the production, all the credit for the outcome should go to the firm. Consequently, even for the same level of positive outcome, because a customer who participates in production gives the firm less credit for the outcome, a participating customer may be less satisfied with the firm than a customer who does not participate in production.

A customer may not be as eager to share responsibility when the outcome is negative or worse than expected. According to the self-serving bias, a customer is less likely to take responsibility for the bad outcome, even though he or she participates in the production. Thus, a customer's satisfaction with the firm may be at the same level when the outcome is negative, regardless of whether the customer participated in the production. Note that if the self-serving bias did not exist, a customer would take some of the blame for the negative outcome when he or she participates in production (comparable to taking credit for the positive outcome), and therefore satisfaction with the firm should be greater when the customer participates in production than when the customer does not.

At times, an outcome is neither better nor worse than expected but simply conforms to an expectation. This situation has not been studied in the self-serving bias literature, and we must look elsewhere to make theoretical predictions about satisfaction in this context. Attribution research provides some insight because it has demonstrated that people are more likely to engage in attributional (cause and effect) thinking when confronted with the unexpected and that, when things are as expected, there is less incentive and, consequently, less effort to figure out who is responsible for what share of the task (Weiner 1985). If this is the case, when an outcome is as expected, we would not expect to find differences in a customer's satisfaction with the firm when the customer participates in the production than when he or she does not.

On the basis of the previous discussion, we propose the following:

$P_{1}$ : When an outcome is better than expected, a customer who participates in production with the firm will be less satisfied with the firm than will a customer who does not participate in production.

$\mathrm{P}_{2}$ : When an outcome is worse than expected, a customer who participates in production with the firm will be as satisfied with the firm as will a customer who does not participate in production.

$\mathrm{P}_{3}$ : When an outcome is as expected, a customer who participates in production with the firm will be as satisfied with the firm as will a customer who does not participate in production.

\section{Method}

Subjects were undergraduate students from a major U.S. university $(n=124)$. All subjects voluntarily participated in 
return for course credit and a chance to win a prize in a lottery. We informed subjects that the objective of the research was to investigate college students' perceptions of their experiences in purchasing various product categories. We gave subjects a booklet describing various purchase experiences to read at their own pace. After reading the scenarios, subjects provided their evaluations.

\section{Stimulus Materials}

We developed scenarios to describe purchases in six product categories. Three involved the purchase of goods: a bookshelf, a poster frame, and custom jeans. Three others were drawn from the services sector: a travel agent, a lawyer, and a weight-loss center. We constructed the scenarios to represent one of the six experimental conditions (two levels of customer participation: participation versus no participation $x$ three outcome levels: better than expected, worse than expected, as expected). We carefully pretested all of the scenarios $(n=49)$ for believability and relevance of the situation to a student population. Believability received average ratings ranging from 5.4 to 6.4 on a seven-point scale anchored by 1 ("not at all believable") and 7 ("very believable"). Relevance received average ratings ranging from 5.3 to 6.2 on a seven-point scale anchored by 1 ("not at all relevant") and 7 ("very relevant"). We also verified the participation manipulation in the pretest. On seven-point scales that measured the extent of work and effort $(1=$ "low" and 7 = "high") by the customer, the participation option was rated as involving significantly more effort (mean effort rating under nonparticipation $=2.42$; mean effort rating under participation $=5.67 ; p<.01$ ) than the nonparticipation option in all six of the scenarios. The same pattern holds for work ratings across all six scenarios (mean work rating under nonparticipation $=2.23$; mean work rating under participation $=5.75 ; p<.01$ )

Each subject received six scenarios, one for each product category, which reflected one of the six experimental conditions. The order of presentation of the scenarios was randomized for each subject. Consistent with prior research, the scenarios described the experiences of an undergraduate named "Pat." The name Pat was chosen to be gender-neutral so that both male and female subjects could identify with the character. Students were asked to put themselves in Pat's shoes and indicate how they thought Pat would respond in each setting. The use of projective scenarios is well established in the psychology and marketing literatures and has been shown to minimize social desirability effects and have considerable external validity (Bateson and Hui 1992; Hui and Bateson 1991; Reeder et al. 2001; Robinson and Clore 2001; Voss, Parasuraman, and Grewal 1998). Even if subjects adopted an "observer" stance, analyzing Pat from a distance, instead of an "actor" stance, in which they put themselves in Pat's shoes, research has shown that it still would represent a conservative test of the hypothesis because Jones and Nisbett (1972), among others, have shown that the selfserving bias is reduced when events related to another as opposed to oneself are explained. Consistent with the discussion provided by Meuter and Bitner (1998), for the scenarios used in this study, nonparticipation involves the customer not participating in the production of the product, and participation involves the customer participating in some part of the production. Meuter and Bitner (1998) illustrate nonparticipation with an attendant pumping gas for the customer and taking payment at the pump. For participation, the customer took on some part of the production: Either the customer pumped the gas and the attendant took payment at the pump or the attendant pumped the gas and the customer paid at the pump using automation. Details of the six scenarios used in this study are presented in Table 2.

The scenarios were crafted with two important considerations: control for customization and independence of outcome quality and participation. Satisfaction in the participation condition may be affected by customization in that, when customers produce the good or service, they can make sure it fits their needs exactly (Wind and Rangaswamy 2000) to the extent that they have the requisite expertise (Lusch, Brown, and Brunswick 1992). For example, when customers fix their salads at a salad bar, they can make sure that it is exactly to their liking. When they communicate these preferences to an employee, they may have problems articulating their wants or the employee may have problems understanding them. To control for this customization aspect, in all of the scenarios, the dialogue between the employee and the customer is kept constant and culminates in the customer's choice of a product. For example, in the bookshelf scenario, Pat is described as talking with the salesperson about the type of shelf needed, inspecting the selection, and selecting one. Following this dialogue, depending on a subject's experimental condition, he or she read either about Pat's nonparticipation or about Pat's participation in production. For example, in the bookshelf scenario, participation is manipulated by having a subject read that the employee tells Pat one of the following two things: either that the store would assemble the shelf and deliver it (nonparticipation condition) or that the store would deliver the parts and Pat could assemble it (participation condition).

Equally important, our manipulation of outcome quality is kept independent of participation in production. That is, subjects in both the participation and nonparticipation conditions read that there were no problems with the actual production. Depending on the experimental condition, subjects simply read that the product turned out better than expected, worse than expected, or as expected in a nonproductionrelated dimension. For example, whether the store or Pat assembled the shelf, there were no problems with the actual construction of the shelf. Outcome quality was presented as the shelf being much sturdier than expected, much less sturdy than expected, or about as sturdy as expected, independent of the customer's participation in production. This provides a conservative test of the self-serving bias.

\section{Measures and Analysis}

After subjects read all scenarios, they provided measures of satisfaction with the firm on a nine-point, single-item scale anchored by 1 ("dissatisfied") and 9 ("satisfied"). In a pretest $(n=41)$, we used a three-item satisfaction scale (dissatisfiedsatisfied, displeased-pleased, terrible-delighted). The reliability coefficient $\alpha$ for the scale was .98, and the first item was highly correlated with the latter two (.94 and .96). Consequently, with the high interitem correlations, the length of 
I. Dialogue between Pat and the employee and selection of product (common to all subjects).

Talks to salesperson and selects the bookshelf to buy (S1).

Talks to salesperson and selects the mat and frame for the poster (S2).

Talks to salesperson and selects the fabric and color for custom-fit jeans (S3).

Talks to lawyer and decides what to say in letter to landlord for a return on security deposit (S4).

Talks to travel agent and selects hotel room to stay at for spring break (S5).

Talks to weight counselor at weight-loss center and selects weight-loss plan (S6).

II. Manipulation of participation in production (between-subjects).

Pat is told the store will assemble and deliver shelf.

Pat is told the store will deliver the shelf parts and Pat must assemble it.

Pat is told the store will build the frame.

Pat is told Pat must build the frame.

The employee takes Pat's measurements for custom-fit jeans and enters them.

The employee takes Pat's measurements for custom-fit jeans and Pat enters them.

The lawyer shows Pat a form letter and drafts and mails it to Pat's landlord.

The lawyer shows Pat a form letter, and Pat drafts and mails it to the landlord.

The travel agent calls to reserve the room for Pat.

Pat calls to reserve the room.

The center uses the food list to shop for Pat's food at the grocery store.

The center gives $P$ at the food list to shop for food at the grocery store.

III. Manipulation of outcome independent of participation (between-subjects).

The shelf is assembled fine, but Pat thinks it is sturdier than expected, much less sturdy than expected, or about as sturdy as expected.

The frame is built fine, but Pat thinks it matches the room much better than expected, much worse than expected, or about as expected.

The jeans are tailored fine, but Pat thinks the color is much better than expected, much worse than expected, or about as expected.

The letter is written fine, but Pat thinks the refund from the landlord is much more than expected, much less than expected, or about as expected.

The room looks fine, but Pat thinks that the view is much better than expected, much worse than expected, or about as expected.

The list is used to shop, but Pat thinks the weight loss is much more than expected, much less than expected, or about as expected.

the task of reading and responding to six scenarios, and precedence in the literature for a single-item measure of satisfaction (e.g., Bitner 1990), we used only the single-item measure in the study to keep the total time to complete the survey reasonable and prevent respondent fatigue. We conducted paired $\mathrm{t}$-tests (participation versus nonparticipation) to test $P_{1}-P_{3}$ (Kirk 1982) for each product within each outcome level (better than expected, as expected, worse than expected). These results are reported in Table 3.

As predicted in $\mathrm{P}_{1}$, in all six scenarios, when the outcome is better than expected, ratings of customer satisfaction with the firm are greater when the customer does not participate in the production than when he or she does. When the outcome is worse than expected, we proposed in $\mathrm{P}_{2}$ that there would be no difference in customer satisfaction with the firm, whether the customer participates in the production or not. In all six scenarios, customer satisfaction rat- ings are not significantly different between the participation and nonparticipation conditions.

When the outcome is as expected, we postulated in $\mathrm{P}_{3}$ that there would be no significant differences in satisfaction with the firm based on participation. This turned out to be the case in four of the six scenarios. In the poster frame and hotel stay scenarios, even when the outcome was as expected, customers appeared to take some of the credit for the outcome in the participation condition, as reflected in lower ratings of satisfaction with the firm when the customer participated in production. Therefore, there is partial support for $\mathrm{P}_{3}$.

\section{Discussion}

Study 1 is the first empirical investigation of the psychological impact of customer participation in production. It is also 


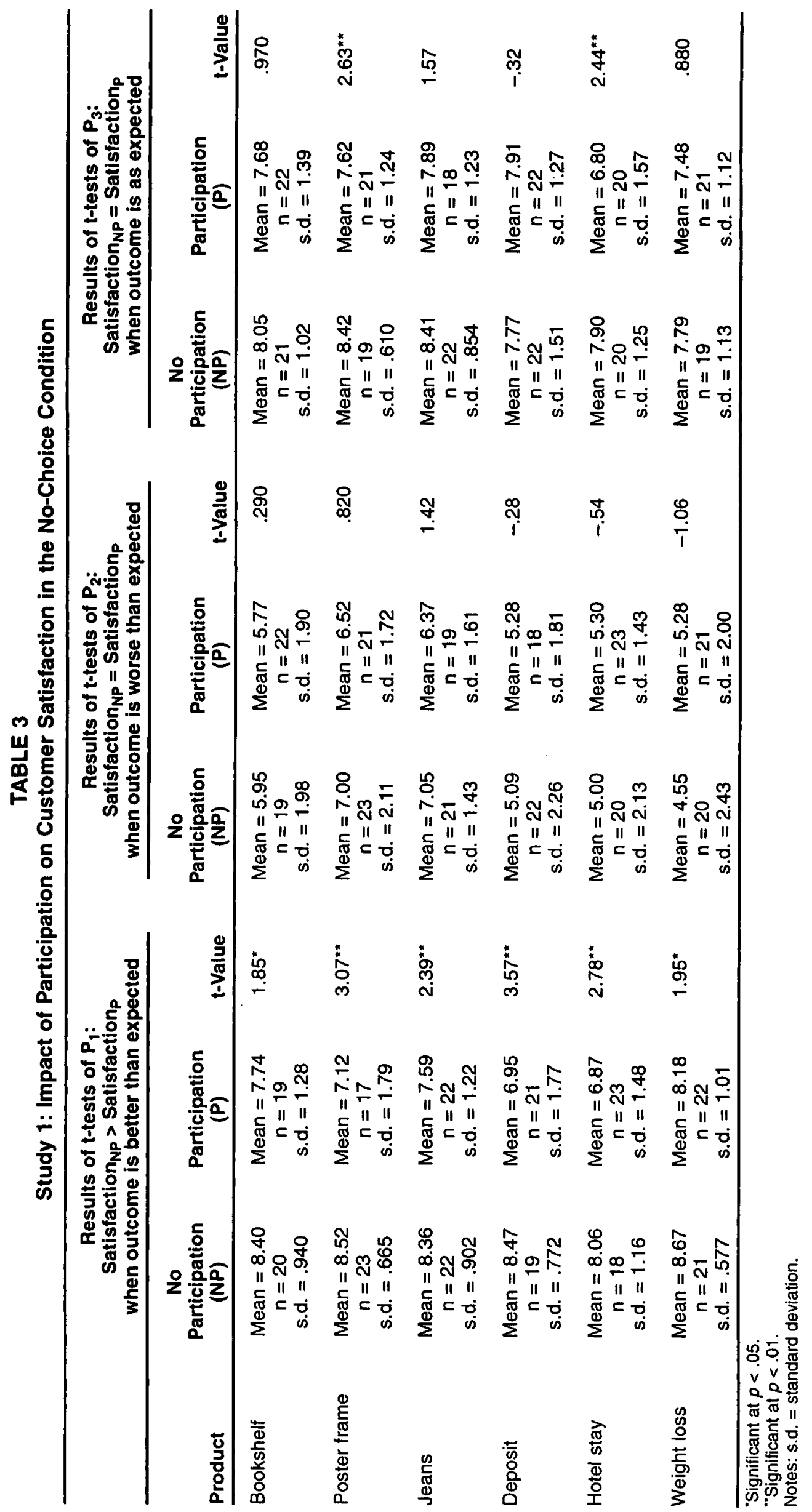


the first to demonstrate the self-serving bias in the commercial atena. From a theoretical perspective, the results of Study 1 have several important implications. Most significant, the study shows that the link between outcome quality and satisfaction with the firm is affected by customer participation in production. This study also extends the selfserving bias literature in two directions. First, it incorporates the "outcome as expected" condition. Second, in the place of bogus feedback by the experimenter in a lab, we demonstrate that the bias exists even when the customer provides the judgment of the outcome.

From a managerial standpoint, these results suggest that firms must evaluate customer participation in production carefully. We find that a customer is far more likely to take credit than to take blame in joint production. Therefore, a firm considering a participation strategy must understand how the self-serving bias can be reduced or whether customers can be made to assume credit as well as blame when they participate in production. This is the focus of Study 2 .

\section{Study 2: Strategies to Reduce the Self-Serving Bias}

In Study 2, we examine conditions in which a customer's self-serving bias can be reduced. The psychological literature suggests that increasing a customer's autonomy in a situation may reduce the self-serving bias. Knee and Zuckerman (1996) define autonomy as a situation that fosters choices and a sense of freedom. Using an individual differences perspective, Knee and Zuckerman show that people who have a high autonomy orientation are less subject to the self-serving bias than are those who have a low autonomy orientation. Therefore, a customer's self-serving bias may be reduced if a firm can (1) select those customers who have a high autonomy orientation or (2) create situations that increase the autonomy for all customers. Identifying and selecting customers on their autonomy orientation may not be feasible for all firms. Consequently, firms may find more value in creating situations that provide choice to foster autonomy. Arkin, Gleason, and Johnston (1976) investigate the effect of providing choice on self-serving bias when a person works alone to produce an outcome. They find that when subjects are provided a choice, they accept responsibility for both positive and negative outcomes. However, when they are not provided a choice, they accept responsibility only for the positive outcome and not for the negative outcome. Study 2 investigates the effect of choice in a joint production context, an area that has not been studied previously.

In Study 2, the effects of participation under choice also are hypothesized to vary on the basis of the outcome quality. Consistent with Study 1, when the outcome is better than expected, satisfaction with the firm should be less for a customer who chooses to participate in production than for a customer who does not. However, in contrast to Study 1, when the outcome is worse than expected, a customer who chooses to participate should take more responsibility for the outcome than one who chooses not to participate, and therefore the former customer should be more satisfied with the firm. Consistent with the attribution literature cited pre- viously, there should not be a significant difference between a customer who chooses to participate and one who chooses not to do so when the outcome is as expected. Consequently, it is proposed that

$\mathbf{P}_{4}$ : When a customer is given a choice of whether to participate in production, if the outcome is better than expected, a customer who chooses to participate in production with the firm will be less satisfied with the firm than will a customer who chooses not to participate.

$P_{5}$ : When a customer is given a choice of whether to participate in production, if the outcome is worse than expected, a customer who chooses to participate in production with the firm will be more satisfied with the firm than will a customer who chooses not to participate.

$P_{6}$ : When a customer is given a choice of whether to participate in production, if the outcome is as expected, a customer who chooses to participate in production with the firm will be as satisfied with the firm as will a customer who chooses not to participate.

\section{Participation and Process Versus Outcome Effects on Satisfaction}

Customers' satisfaction has been shown to be influenced by both the outcome, or what they receive in the relationship, and the process, or how they receive the outcome (Tax, Brown, and Chandrashekaran 1998). It is possible that the relative weighting of the outcome and the process dimension in determining overall satisfaction may be different for customers who participate in production versus those who do not. There has been no direct, theoretical consideration or empirical test in the literature of this idea of differential impacts of process and outcome based on participation. However, equity theory (Adams 1963; Oliver and Swan 1989), which postulates that individuals' comparison of their inputs and outputs with those of a relational partner affects their overall satisfaction with the relationship, provides a useful framework to examine this notion. In an automobile purchase setting, Swan and Oliver (1991) find that customers monitor their inputs such as their attention, time, and effort and that these affect overall satisfaction. That is, customers' assessment of their own input affects their overall satisfaction. Our study extends Swan and Oliver's work in two ways. First, customer input, participation in production, is by choice in our study, whereas in Swan and Oliver's work, it is not. Second, the input in Swan and Oliver's (1991) study is in the form of negotiation, search, and attention during the car buying process. In contrast, in our study, customer input is even more significant because it constitutes participation in the actual process of production. Thus, building on equity theory and Swan and Oliver (1991), the impact of the production process on overall satisfaction may be greater for those customers who choose to participate in production than for those who choose not to participate. By extension, the impact of the outcome on overall satisfaction may be less important to customers who choose to participate in production than to those who choose not to. Consequently, we propose that

$P_{7}$ : A customer's satisfaction with a firm is affected by satisfaction with both the process and the outcome.

$P_{8}$ : When a customer chooses to participate in production, the effect of the process satisfaction on firm satisfaction will be greater than when he or she chooses not to participate. 
$\mathrm{P}_{9}$ : When a customer chooses to participate in production, the effect of the outcome satisfaction on firm satisfaction will be lower than when he or she chooses not to participate.

\section{Method}

Participants were undergraduate students from a major U.S. university $(n=135)$ recruited in identical conditions to those described in Study 1.

\section{Stimulus Materials}

To achieve comparability across studies, we employed the same scenarios used in Study 1, with one important modification. In Study 2, after the dialogue, the subjects read that the firm gave Pat a choice as to whether to participate in the production. Subsequently, depending on the randomly assigned experimental condition, respondents read that Pat either chose to participate (e.g., chose to build the shelf) or chose not to participate (e.g., chose to have the store build the shelf) in the production process. Respondents in all scenarios read that Pat considered the money, time, effort, costs, and benefits involved in both alternatives before making the decision whether to participate. As with Study 1, we kept the outcome manipulation independent of participation and focused on the same nonproduction-related aspects. The task and order of presentation of stimulus materials were identical to Study 1.

\section{Measures and Analysis}

After subjects read each scenario, they provided measures of satisfaction with the firm and with the process involved using single-item, nine-point scales $(1=$ "dissatisfied" and $9=$ "satisfied"). To test $\mathrm{P}_{4}-\mathrm{P}_{6}$, we conducted paired t-tests to compare ratings of satisfaction with the firm when the customer chose to participate in production versus when he or she chose not to participate (Kirk 1982) for each product within each outcome level (better than expected, as expected, worse than expected). These results are shown in Table 4.

When Pat is described as having a choice of whether to participate, and the outcome is better than expected, firm satisfaction ratings are significantly greater when Pat chooses not to participate in production than when Pat chooses to participate in five of the six scenarios. This provides support for $\mathrm{P}_{4}$ and replicates the findings of Study 1 . The single exception is the poster frame condition for which the difference is in the expected direction but is not significant.

As proposed in $\mathrm{P}_{5}$, when the outcome is worse than expected, firm satisfaction ratings are significantly higher when Pat chooses to participate in production than when Pat chooses not to do so in four of the six scenarios. The differences are not significant in the poster frame and the weightloss conditions. Overall, the pattern of results provides support for $\mathrm{P}_{5}$ and, more important, reveals a reversal of the results found in Study 1. Thus, choice mitigates the use of self-serving bias when the outcome is worse than expected.

When the outcome is as expected, we proposed there would be no significant differences in ratings of satisfaction with the firm based on customer participation. This was the case in four of the six scenarios, which provides some support for $\mathrm{P}_{6}$. In the deposit and the hotel stay scenarios, even when the outcome is as expected, in the participation choice condition Pat is given some of the credit for the outcome, as reflected in lower satisfaction with the firm.

In $\mathrm{P}_{7}-\mathrm{P}_{9}$, we proposed customers' satisfaction with the outcome would be affected by their satisfaction with both the process and the actual outcome. Furthermore, we proposed that customers' sensitivity to outcome and process would vary on the basis of their choice of participation in production. Specifically, we expected that a customer would be less sensitive to the outcome and more sensitive to the process when he or she chooses to participate in production than when he or she does not, thus accounting for the muted effect of the actual outcome on satisfaction.

To test these propositions, we conducted regression analyses for each product; satisfaction with the firm was the dependent variable and two dummy-coded outcome variables (dummy variables for "better than expected" and "worse than expected," with the "as expected" condition as the baseline comparison), and satisfaction with the process was the independent variables. These results are shown in Table 5.

As shown in the pooled condition in Table 5 and suggested in $\mathrm{P}_{7}$, satisfaction with the process had a significant effect in all six scenarios. Also, as predicted, the outcome being worse than expected had a significant, negative effect in all six of the scenarios. The outcome being better than expected was not significantly different in any of the six scenarios. Recall that the comparison of the outcomes is with the "as expected" condition.

To determine whether the relative effects are different when a customer chooses to participate versus when he or she does not, we ran two additional regressions for the participation (P) and nonparticipation (NP) choice conditions. Comparing the results from these two regressions with those from the pooled regression allows for a test to be performed for the equality of beta coefficients across the two conditions. The results are shown in Table 5.

The results from the test for the equality of coefficients demonstrate that the relative weights for outcome and process are not the same across participation versus nonparticipation conditions. As predicted, the beta coefficients indicate that the outcome effects are stronger and the process effects are weaker in the nonparticipation condition than in the participation condition. Specifically, satisfaction with the process had greater influence on satisfaction with the firm in the participation condition than in the nonparticipation condition for all six scenarios. In all six cases, though not significant, directionally, the coefficients for the better than expected condition are larger in the nonparticipation condition than in the participation condition. In five of the six cases, the coefficients indicate that a worse than expected outcome reduces firm satisfaction to a greater degree in the nonparticipation condition than in the participation condition. The exception is the weight-loss scenario, for which the test for equality of coefficients indicates that relative effects were not significantly different.

\section{Discussion}

The results of Study 2 show that providing choice in participation can reduce the self-serving bias and thus make a customer more willing to take the credit as well as the blame for 


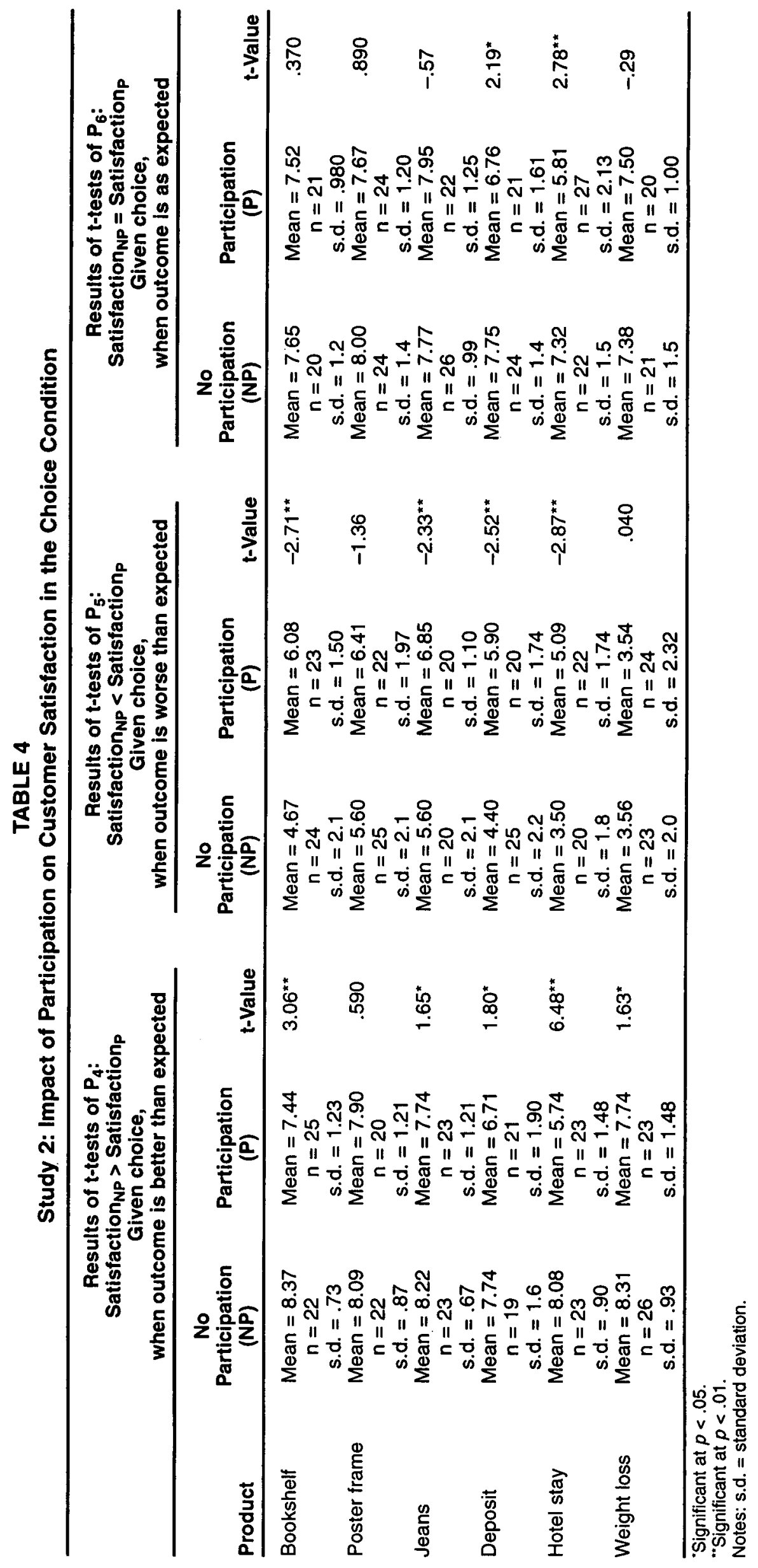


TABLE 5

Results from Regressing Process and Outcome on Satisfaction with the Firm (Pooled) and Comparison of Standardized Beta Coefficients Under Participation (P) and Nonparticipation (NP)

\begin{tabular}{|c|c|c|c|c|c|c|}
\hline Product & Condition & Process $\beta$ & $\begin{array}{c}\text { Better than } \\
\text { Expected } \\
\text { Outcome } \beta \\
\end{array}$ & $\begin{array}{l}\text { Worse than } \\
\text { Expected } \\
\text { Outcome } \beta\end{array}$ & $\mathbf{N}$ & $\begin{array}{l}\text { Pooling } \\
\text { Test } \\
\text { F-Value }\end{array}$ \\
\hline \multirow[t]{2}{*}{ Bookshelf } & Pooled & $.427^{\star * *}$ & .027 & $-.472^{\star * *}$ & 131 & \multirow{2}{*}{$4.92^{* \star \star *}$} \\
\hline & $\stackrel{P}{\mathrm{PP}}$ & $\begin{array}{l}.540^{* \star *} \\
.340^{* * *}\end{array}$ & $\begin{array}{c}-.05 \\
.094\end{array}$ & $\begin{array}{l}-.344^{* * *} \\
-.574^{* * *}\end{array}$ & $\begin{array}{l}67 \\
64\end{array}$ & \\
\hline \multirow[t]{2}{*}{ Poster frame } & Pooled & $.384^{* \star \star}$ & .065 & $-.378^{\star \star \star *}$ & 133 & \multirow{2}{*}{$2.52^{* \star}$} \\
\hline & $\begin{array}{c}P \\
\text { NP }\end{array}$ & $\begin{array}{l}.524^{\star \star \star} \\
.282^{\star \star \star *}\end{array}$ & $\begin{array}{l}.055 \\
.056\end{array}$ & $\begin{array}{l}-.309^{\star \star \star \star} \\
-.401^{* \star \star}\end{array}$ & $\begin{array}{l}67 \\
66\end{array}$ & \\
\hline \multirow[t]{2}{*}{ Jeans } & Pooled & $.368^{* \pm *}$ & -.01 & $-.430^{* * *}$ & 130 & \multirow{2}{*}{$4.68^{* \star *}$} \\
\hline & $\begin{array}{c}P \\
\text { NP }\end{array}$ & $\begin{array}{l}.532^{* * *} \\
.330^{* * *}\end{array}$ & $\begin{array}{l}-.04 \\
.005\end{array}$ & $\begin{array}{l}-.220^{\star} \\
-.588^{\star \star \star}\end{array}$ & $\begin{array}{l}63 \\
67\end{array}$ & \\
\hline \multirow[t]{2}{*}{ Deposit } & Pooled & $.189^{* * *}$ & -.04 & $-.435^{* * *}$ & 126 & \multirow{2}{*}{$4.61^{* \star *}$} \\
\hline & $\stackrel{P}{N P}$ & $\begin{array}{l}.249^{* \star \star} \\
.219^{* \star \star}\end{array}$ & $\begin{array}{r}-.08 \\
.030\end{array}$ & $\begin{array}{l}-.157^{\star} \\
-.583^{\star * \star}\end{array}$ & $\begin{array}{l}60 \\
66\end{array}$ & \\
\hline \multirow[t]{2}{*}{ Hotel stay } & Pooled & $.440^{* * *}$ & .100 & $-.355^{\star \star \star *}$ & 133 & \multirow{2}{*}{$8.20^{* \star \star}$} \\
\hline & $\stackrel{P}{N P}$ & $\begin{array}{l}.478^{* * \star} \\
.277^{* * *}\end{array}$ & $\begin{array}{l}.058 \\
.111\end{array}$ & $\begin{array}{l}-.111 \\
-.627^{\star \star \star}\end{array}$ & $\begin{array}{l}70 \\
63\end{array}$ & \\
\hline \multirow[t]{2}{*}{ Weight loss } & Pooled & $.238^{* \star \star}$ & .096 & $-.617^{* * *}$ & 133 & \multirow{2}{*}{.56} \\
\hline & $\begin{array}{c}\mathrm{P} \\
\mathrm{NP}\end{array}$ & $\begin{array}{l}.252^{\star \star \star} \\
.233^{\star \star \star}\end{array}$ & $\begin{array}{l}.011 \\
.175^{\star \star}\end{array}$ & $\begin{array}{l}-.628^{\star \star \star \star} \\
-.605^{\star \star \star}\end{array}$ & $\begin{array}{l}65 \\
68\end{array}$ & \\
\hline
\end{tabular}

Significant at $p<.10$

" Significant at $p<.05$.

$\cdots$ Significant at $p<.01$.

an outcome. When a firm provides a participation choice to a customer, the firm still must decide carefully on a customer participation strategy on the basis of an understanding of the product and its likelihood of falling short versus exceeding a customer's expectations. If a firm believes the outcome will exceed a customer's expectations, encouraging participation may be less attractive because a customer is likely to claim some of the credit when he or she participates. However, if there is some chance that the outcome will not meet a customer's expectations, encouraging customer participation may be a reasonable strategy because the firm may receive less blame for the outcome.

For many companies, a risk-averse strategy may be used to encourage the customer to participate in production to reduce the negative effects of a potential shortfall relative to customer expectations. This may be the safer route to take for two reasons. First, several researchers have shown that the effect of performance on satisfaction is asymmetric (Zeithaml, Berry, and Parasuraman 1996). When a firm falls short of expectations, the penalty in customer satisfaction is far steeper than the benefit when the firm exceeds expectations. Second, in many cases it may be relatively difficult and expensive to try to exceed customer expectations.
In both studies, it appears that a customer takes more responsibility than is warranted when he or she participates. This is because there was an explicit manipulation of outcome quality independent of whether a customer participated in production. In reality, when a customer's participation actually affects the outcome quality, we would expect the effects to be even more pronounced. The insights into how participation choice affects customer satisfaction with the firm are also noteworthy. The standardized beta weights in Table 5 reveal that the impact of a worse than expected outcome can be reduced anywhere from one-third (poster frame scenario) to as much as five times (hotel scenario) when the customer participates in production. Furthermore, focus on the process increases from approximately oneseventh (deposit scenario) to almost two times (poster frame scenario) when a customer participates in production compared with when he or she does not participate. Therefore, when the customer is engaged in production, the firm must ensure that the process of production is involving and of high quality. The process must provide psychic benefits to the customer, whether in the form of enjoyment, accomplishment, self-confidence, or control (Lusch, Brown, and Brunswick 1992). 


\section{Conclusion and Directions for Further Research}

The research reported here provides evidence for the psychological impact of a customer's participation in production. We show that a customer who participates in production is subject to the self-serving bias and that this tendency is reduced when a customer has a choice of whether he or she will participate in production. Further research is needed to investigate other potential avenues for minimizing the self-serving bias.

Previous research demonstrates that people are less likely to engage in the self-serving bias for joint outcomes when they have a close relationship with the partner. For example, Campbell and colleagues (2000) show that the self-serving bias is significantly lower when the subjects working together are friends rather than strangers. As a person becomes closer to a partner, he or she is still likely to overstate his or her role but does so in a more symmetric fashion and shares the credit as well as the blame (Gilovich, Kruger, and Savitsky 1999). This effect holds even when the closeness is lab induced. For example, Sedikides and colleagues (1998) show that strangers who were made to feel close to each other through an experimental manipulation demonstrated a reduced self-serving bias. These results suggest that when a customer has a close relationship with a firm, he or she may be less subject to the self-serving bias. Therefore, from a strategic point of view, firms may want to encourage participation in production by customers who have a strong relationship with the firm. However, even when dealing with long-established customers, a firm must carefully assess the customer's willingness and ability to participate in production. For example, a customer may have a strong, long-term relationship with the firm precisely because the firm does everything for him or her and he or she does not need to participate in producing the good or service. If the firm now tries to cajole the customer into coproduction, the customer may become dissatisfied and may switch to another company.

Researchers have also contended that distinct cultural differences exist in the likelihood of a self-serving bias, and the bias is more prevalent in individualistic cultures, such as the United States, than in collectivist cultures, such as many Asian countries (Heine and Lehman 1997). Although these cultural differences have been examined in interpersonal relationships, it would be interesting to know whether they translate to firm-customer relationships as well. In addition to cultural differences, there may be individual differences in willingness to accept responsibility. Constructs such as the locus of control (Rotter 1966) may be used to examine whether some people are more likely to be affected by participation in production than others.

Another area for additional research is the timing of a customer's participation. That is, in addition to how much participation, does it matter when a customer partici- pates? The studies reported here do not distinguish between when a customer participates in production. For example, a customer may choose to participate in the initial phase of the production process and then hand off the project to the firm (e.g., a customer who paints a ceramic vase and turns it over for glazing). Or a customer may choose to participate in the end phase of the production (e.g., a customer who has a firm build a deck and then applies the sealer). The management literature on job design suggests that creating task identity-allowing employees to be fully responsible for one aspect of the work -increases employees' awareness of how their piece of work fits into the whole, and this increases their job satisfaction (Hackman and Oldham 1976). If this relationship also holds for a customer, firms may do well to select the choice points for customer participation carefully so that they stand out as separate and distinct to the customer.

In current literature, there is an assumption that coproduction always facilitates better customization of the product (Wind and Rangaswamy 2000). However, the assumption of greater customization under co-production may hold only when the customer has the expertise to craft a good or service to his or her liking (Lusch, Brown, and Brunswick 1992). Furthermore, perceived expertise may affect the customer's psychological responses to co-production. A customer who believes he or she has the expertise and chooses to co-produce may be more likely to make self-attributions for success and failure than a customer who lacks the expertise. A customer who lacks the expertise but feels forced to co-produce (e.g., a customer who enters a department store seeking help from store personnel but is forced to make decisions on his or her own because of the scarcity of store personnel) may make more negative attributions about co-production.

We adopt a narrow view of customer co-production in this article, focusing on customer participation in the construction of goods and services. However, consumer coproduction extends to the construction of meanings as well. Consumers are not just passive receptacles of brand identities projected by marketers; they are active co-producers of brand meanings (Cova 1996; Firat and Venkatesh 1993; Ritson and Elliott 1999). Greater attention to the implications of such consumer co-produced marketing images is warranted given the empowerment of consumers through the Internet and customers' militancy in protecting their brand icons (Levine et al. 2001). Another limitation is the reliance on single-item measures of satisfaction. Even though the decision to use the single items was driven by high intercorrelations among multi-item measures in pretests and a concern for reducing respondent fatigue, further research should consider using multi-item measures for the variables to investigate whether these provide stronger tests and greater insight.

\section{REFERENCES}

Adams, J. Stacy (1963), "Toward an Understanding of Inequity," Journal of Abnormal and Social Psychology, 67 (November), 422-36.

Arkin, Robert M., James M. Gleason, and Shawn Johnston (1976), "Effect of Perceived Choice, Expected Outcome, and Observed

Outcome of an Action on the Causal Attributions of Actors," Journal of Experimental Social Psychology, 12 (2), 151-58.

Bateson, John E.G. (1985), "Self-Service Consumer: An Exploratory Study," Journal of Retailing, 61 (3), 49-76.

and Michael K. Hui (1992), "The Ecological Validity of 
Photographic Slides and Videotape," Journal of Consumer Research, 19 (2), 271-81.

Bitner, Mary Jo (1990), "Evaluating Service Encounters: The Effects of Physical Surrounding and Employee Responses," Journal of Marketing, 54 (April), 69-82.

Bowen, John (1990), "Development of a Taxonomy of Services to Gain Strategic Marketing Insights," Journal of the Academy of Marketing Science, 18 (1), 43-49.

Bowers, Michael R., Charles L. Martin, and Alan Luker (1990), "Trading Places: Employees as Customers, Customers as Employees," The Journal of Services Marketing, 4 (2), 55-69.

Campbell, W. Keith and Constantine Sedikides (1999), "SelfThreat Magnifies the Self-Serving Bias: A Meta-Analytic Integration," Review of General Psychology, 3 (1), 23-43.

- - - Glenn D. Reeder, and Andrew J. Elliott (2000), "Among Friends? An Examination of Friendship and the SelfServing Bias," British Journal of Social Psychology, 39 (2), 229-39.

Cermak, Dianne S.P., Karen Maru File, and Russ Alan Prince (1994), "Customer Participation in Service Specification and Delivery," Journal of Applied Business Research, 10 (2), 90-100.

Cova, Bernard (1996), "What Postmodernism Means to Marketing Managers," European Management Journal, 14 (5), 494-99.

Curren, Mary T., Valerie S. Folkes, and Joel H. Steckel (1992), "Explanations for Successful and Unsuccessful Marketing Decisions: The Decision Maker's Perspective," Journal of Marketing, 56 (April), 18-31.

Czepiel, John A. (1990), "Service Encounters and Service Relationships: Implications for Research," Journal of Business Research, 20 (1), 13-21.

Dabholkar, Pratibha (1990), "How to Improve Perceived Service Quality by Improving Customer Participation," in Developments in Marketing Science, B.J. Dunlap, ed. Cullowhee, NC: Academy of Marketing Science, 483-87.

(1996), "Consumer Evaluations of New Technology Based Self-Service Options," International Journal of Research in Marketing, 13 (1), 29-51.

Firat, A. Fuat, Nikhilesh Dholakia, and Alladi Venkatesh (1995), "Marketing in a Postmodern World," European Journal of Marketing, 29 (1), 40-56.

- and Alladi Venkatesh (1993), "'Postmodernity' in the Age of Marketing," International Journal of Research in Marketing, $10(1), 227-49$.

_ and (1995), "Liberatory Postmodernism and the Reenchantment of Consumption," Journal of Consumer Research, 22 (3), 239-67.

Fitzsimmons, James A. (1985), "Consumer Participation and Productivity in Service Operations," Interfaces, 15 (3), 60-67.

Fodness, Dale, Barry E. Pitegoff, and Elise Truly Sautter (1993), "From Customer to Competitor: Consumer Co-Option in the Service," The Journal of Services Marketing, 7 (3), 18-25.

Folkes, Valerie S. (1988), "Recent Attribution Research in Consumer Behavior: A Review and New Directions," Journal of Consumer Research, 14 (4), 548-65.

Gilovich, Thomas, Justin Kruger, and Kenneth Savitsky (1999), "Everyday Egocentrism and Everyday Interpersonal Problems," in The Social Psychology of Emotional and Behavioral Problems, R.M. Kowalski and M.R. Leary, eds. Washington, DC: American Psychological Association, 69-95.

Goodwin, Cathy (1988), "I Can Do It Myself: Training the Service Consumer to Contribute," The Journal of Services Marketing, 2 (4), 71-78.

Hackman, J. Richard and Greg R. Oldham (1976), "Motivation Through Design of Work: Test of a Theory," Organizational Behavior and Human Decision Processes, 16 (2), 250-79.

Heine, Steven J. and Darrin R. Lehman (1997), "The Cultural Construction of Self-Enhancement: An Examination of GroupServing Biases," Journal of Personality \& Social Psychology, $72(6), 1268-83$
Heskett, James L., W. Earl Sasser Jr., and Leonard A. Schlesinger (1997), The Service Profit Chain: How Leading Companies Link Profit and Growth to Loyalty, Satisfaction, and Value. New York: The Free Press.

Hui, Michael K. and John E.G. Bateson (1991), "Perceived Control and the Effects of Crowding and Consumer Choice on the Service Experience," Journal of Consumer Research, 18 (2), 174-84.

Hult, G. Tomas M. and Bryan A. Lukas (1995), "Classifying Health Care Offerings to Gain Strategic Marketing Insights," The Journal of Services Marketing, 9 (2), 36-48.

Johnston, William A. (1967), "Individual Performance and SelfEvaluation in a Simulated Team," Organizational Behavior and Human Performance, 2 (3), 309-28.

Jones, Edward E. and Richard E. Nisbett (1972), "The Actor and the Observer: Divergent Perceptions of the Causes of Behavior," in Attribution: Perceiving the Causes of Behavior, E.E. Jones, D.E. Kanouse, H.H. Kelley, R.E. Nisbett, S. Valins, and B. Weiner, eds. Morristown, NJ: General Learning Press, 79-94.

Kelley, Scott W., James H. Donnelly Jr., and Steven J. Skinner (1990), "Customer Participation in Service Production and Delivery," Journal of Retailing, 66 (3), 315-35.

Kirk, Roger E. (1982), Experimental Design Procedures for the Behavioral Sciences, 2d ed. Belmont, CA: Brooks/Cole Publishing.

Knee, C. Raymond and Miron Zuckerman (1996), "Causality Orientations and the Disappearance of the Self-Serving Bias," Journal of Research in Personality, 30 (1), 76-87.

Lengnick-Hall, Cynthia A. (1996), "Customer Contributions to Quality: A Different View of the Customer-Oriented Firm," The Academy of Management Review, 21 (3), 791-824.

Levine, Rick, Christopher Locke, Doc Searls, and David Weinberger (2001), The Cluetrain Manifesto: The End of Business as Usual. Cambridge, MA: Perseus Publishing.

Lovelock, Christopher H. and Robert F. Young (1979), "Look to Consumers to Increase Productivity," Harvard Business Review, 57 (May-June), 168-78.

Lusch, Robert F., Stephen W. Brown, and Gary Brunswick (1992), "A General Framework for Explaining Internal vs. External Exchange," Journal of the Academy of Marketing Science, 20 (2), 119-34.

Meuter, Matthew L. and Mary Jo Bitner (1998), "Self-Service Technologies: Extending Service Frameworks and Identifying Issues for Research," in AMA Winter Educators' Conference, Dhruv Grewal and Connie Pechmann, eds. Chicago: American Marketing Association, 12-19.

—_, Amy L. Ostrom, Robert I. Roundtree, and Mary Jo Bitner (2000), "Self-Service Technologies: Understanding Customer Satisfaction with Technology-Based Service Encounters," Journal of Marketing, 64 (July), 50-64.

Miller, Dale T. and Michael Ross (1975), "Self-Serving Biases in the Attribution of Causality: Fact or Fiction?" Psychological Bulletin, 82 (2), 213-25.

Mills, Peter K., Richard B. Chase, and Newton Margulies (1983), "Motivating the Client/Employee System as a Service Production Strategy," The Academy of Management Review, 8 (2), $301-10$.

- and Dennis J. Moberg (1982), "Perspectives on the Technology of Service Operations," The Academy of Management Review, 7 (3), 467-78.

- and James H. Morris (1986), "Clients as 'Partial' Employees of Service Organizations: Role Development in Client Participation," The Academy of Management Review, 11 (4), 726-35.

Moyers, Bill (1989), "Image and Reality in America: Consuming Images," The Public Mind, Public Broadcasting System (November 8).

Oliver, Richard L. and John E. Swan (1989), "Consumer Perceptions of Interpersonal Equity and Satisfaction in Transactions: 
A Field Survey Approach," Journal of Marketing, 53 (April), $21-35$.

Peppers, Don and Martha Rogers (1997), Enterprise One To One. New York: Doubleday.

Prahalad, C.K. and Venkatram Ramaswamy (2000), "Co-opting Customer Competence," Harvard Business Review, 78 (January-February), 79-87.

Reeder, Glenn D., Matthew Hesson-McInnis, Josuha O. Kroshe, and Elizabeth A. Scialabba (2001), "Inferences About Effort and Ability," Personality and Social Psychology Bulletin, 27 (9), 1225-35.

Ritson, Mark and Richard Elliot (1999), "The Social Uses of Advertising: An Ethnographic Study of Adolescent Advertising Audiences," Journal of Consumer Research, 26 (3), 260-77.

Robinson, Michael D. and Gerlad L. Clore (2001), "Simulation, Scenarios, and Emotional Appraisal: Testing the Convergence of Real and Imagined Reactions to Emotional Stimuli," Personality and Social Psychology Bulletin, 27 (11), 1520-32.

Rotter, Julian B. (1966), "Generalized Expectancies for Internal Versus External Controls of Reinforcement," Psychological Monographs, 80 (1), 1-28.

Schneider, Benjamin and David E. Bowen (1995), Winning the Service Game. Boston: Harvard Business School Press.

Sedikides, Constantine, W. Keith Campbell, Glenn D. Reeder, and Andrew J. Elliott (1998), "The Self-Serving Bias in Relational Context," Journal of Personality and Social Psychology, 74 (2), 378-86.

Song, Jae H. and Carl R. Adams (1993), "Differentiation Through Customer Involvement in Production or Delivery," Journal of Consumer Marketing, 10 (2), 4-12.

Swan, John E. and Richard L. Oliver (1991), "An Applied Analysis of Buyer Equity Perceptions and Satisfaction with Automo- bile Salespeople," Journal of Personal Selling \& Sales Management, 11 (2), 15-25.

Tax, Stephen S., Stephen W. Brown, and Murali Chandrashekaran (1998), "Customer Evaluations of Service Complaint Experiences: Implications for Relationship Marketing," Journal of Marketing, 62 (April), 60-76.

Van Raaij, W. Fred and Ad Th.H. Pruyn (1998), "Customer Control and Evaluation of Service Validity and Reliability," Psychology \& Marketing, 15 (8), 811-32.

Voss, Glenn B., A. Parasuraman, and Dhruv Grewal (1998), "The Roles of Price, Performance, and Expectations in Determining Satisfaction in Service Exchanges," Journal of Marketing, 62 (October), 46-61.

Weiner, Bernard (1985), "An Attributional Theory of Achievement Motivation and Emotion," Psychological Review, 92 (4), 548-73.

Wind, Jerry and Arvind Rangaswamy (2000), "Customerization: The Next Revolution in Mass Customization," Marketing Science Institute Working Paper No. 00-108. Cambridge, MA: Marketing Science Institute.

Wolosin, Robert J., Steven J. Sherman, and Amnon Till (1973), "Effects of Cooperation and Competition on Responsibility Attribution After Success and Failure," Journal of Experimental Social Psychology, 9 (3), 220-35.

Zeithaml, Valarie A., Leonard L. Berry, and A. Parasuraman (1993), "The Nature and Determinants of Customer Expectations of Service," Journal of the Academy of Marketing Science, 21 (1), 1-12. — - - and (1996), "The Behavioral Consequences of Service Quality," Journal of Marketing, 60 (April), 31-46.

Zuckerman, Miron (1979), "Attribution of Success and Failure Revisited: Or the Motivational Bias Is Alive and Well in Attribution Theory," Journal of Personality, 47 (2), 245-87. 